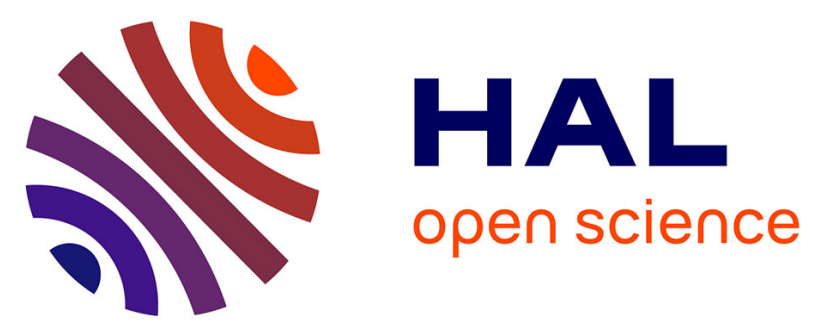

\title{
Pre-employment examination for low back risk in workers exposed to manual handling of loads: French guidelines.
}

Audrey Petit, S. Rousseau, Jean-François Huez, Philippe Mairiaux, Yves Roquelaure

\section{To cite this version:}

Audrey Petit, S. Rousseau, Jean-François Huez, Philippe Mairiaux, Yves Roquelaure. Pre-employment examination for low back risk in workers exposed to manual handling of loads: French guidelines.. International Archives of Occupational and Environmental Health, 2016, 89 (1), pp.1-6. 10.1007/s00420-015-1040-3 . hal-01388728

\section{HAL Id: hal-01388728 \\ https://hal.science/hal-01388728}

Submitted on 8 Oct 2021

HAL is a multi-disciplinary open access archive for the deposit and dissemination of scientific research documents, whether they are published or not. The documents may come from teaching and research institutions in France or abroad, or from public or private research centers.
L'archive ouverte pluridisciplinaire HAL, est destinée au dépôt et à la diffusion de documents scientifiques de niveau recherche, publiés ou non, émanant des établissements d'enseignement et de recherche français ou étrangers, des laboratoires publics ou privés. 


\title{
Pre-employment examination for low back risk in workers exposed to manual handling of loads: French guidelines
}

\author{
A. Petit $\cdot$ S. Rousseau $\cdot$ J. F. Huez $\cdot$ Ph. Mairiaux $\cdot$ \\ Y. Roquelaure
}

\begin{abstract}
Background Low back pain (LBP) is a major cause of sickness absence and disability in the working population, and the pre-employment examination should insure that worker's state of health is compatible with the requirements of proposed job. This paper summarizes the main recommendations of the good practice guidelines of the French Society of Occupational Medicine for pre-employment examination in workers exposed to manual handling of loads apart from pre-employment test.

Methods The recommendations were developed according to the Clinical Practice Guidelines proposed by the French National Health Authority and based on a systematic search of the literature 1990-2012 in several databases. The guidelines were written and reviewed by two multidisciplinary committees. On the basis of the level of evidence in the literature, the proposed guidelines are classified as grade $\mathrm{A}, \mathrm{B}, \mathrm{C}$ or expert consensus.
\end{abstract}

\section{A. Petit · J. F. Huez · Y. Roquelaure}

Faculty of Medicine of Angers, Laboratory of Ergonomics

and Epidemiology in Occupational Health, LUNAM University, Angers, France

J. F. Huez

e-mail: jean-francois.huez@univ-angers.fr

Y. Roquelaure

e-mail: yvroquelaure@chu-angers.fr

A. Petit · Y. Roquelaure

Occupational Health Department, University Hospital of Angers,

Angers, France

\section{A. Petit $(\square)$}

Centre de consultations de pathologie professionnelle, CHU Angers, 4 rue Larrey, 49933 Angers Cedex 9, France

e-mail: aupetit@chu-angers.fr
Results The main recommendations of these guidelines are as follows: (1) medical contraindications alone should not exclude employment in a job associated with a low back risk on the basis of a history of "simple" nonspecific LBP; (2) the relevance of examining a previous history of LBP, which is the best predictor of future LBP due to the recurrent nature of LBP.

Conclusions These guidelines correspond to a constant concern with prevention of occupational risk. Primarily intended for occupational physicians, they are also intended for general practitioners who carry out preemployment examinations in many countries and are likely to be increasingly faced with this type of situation because of the combination of increasing work constraints with ageing of the workforce.

Keywords Pre-employment $\cdot$ Low back risk . Low back pain - Guidelines - Recommendations · Manual handling of loads

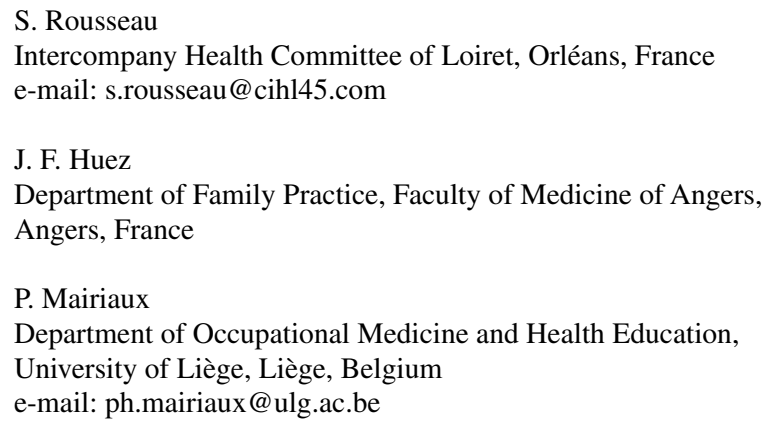




\section{Introduction}

The pre-employment examination is defined as "the assessment of a job applicant's capacity to work without risk to their own or others' health and safety" (Cox et al. 2000; Serra et al. 2007). It should ensure that the worker's state of health is compatible with the requirements of the proposed job, by taking the worker's medical and socioeconomic context into account. Pre-employment examinations may have different aims. On the one hand, pre-employment examination has a preventive character and serves to provide information to the employee about the discrepancies between the work demands and the individual health state. On the other hand, pre-employment testing is an obligatory test to be passed by employee as a condition of employment set by the employer or by regulation. However, the dilemma with pre-employment examinations is that, although rejection of job applicants may prevent an occupational disease or injury, it also may mean that the worker is denied employment. It is thus not possible to be certain whether screening does more harm than good. According to the literature, the pre-employment examination may be useful in specific job conditions, for example in jobs that have specific health risks (Hulshof et al. 1999), and should target specific occupational groups to increase their effectiveness (Braddick et al. 1992; Whitaker and Aw 1995). Both the European and the French regulations do not contain any direct legal requirement of pre-employment test for suitability of employees that will be exposed to manual handling of loads.

Back disorders are a major cause of sickness absence and disability in the working population, and they are therefore a significant economic burden. Both environmental characteristics and individual factors have been identified as risk factors (Elliott et al. 1999; Macfarlane et al. 2006; Manchikanti 2000). First, several authors have demonstrated that jobs requiring heavy manual handling, standing or walking for more than $2 \mathrm{~h}$ result in a higher incidence of low back pain (LBP); (Bakker et al. 2009; da Costa and Vieira 2010; Heneweer et al. 2011; Hoogendoorn et al. 1999; Kuiper et al. 1999; Lotters et al. 2003; Nelson and Hughes 2009). Additionally, a previous history of LBP, particularly if associated with sickness absence of more than a month, or if they have been more than two previous episodes, or co-morbidity with depression, has been found to be associated with increased sickness absence (Johns et al. 1994; Poole 1999; Smedley et al. 1997; Waddell and Burton 2001). Although the physical demands of work may be a relatively modest factor in the primary causation of LBP, people who have LBP do have more difficulty managing physically demanding work (Müller et al. 1999; Waddell 1998). Consequently, there is a pragmatic argument that individuals at highest risk of LBP should not be placed in jobs that impose the greatest physical demand.

The ever-changing work environment, with increasing work constraints, combined with ageing of the workforce will probably increase the frequency of LBP at work. However, refusal of employment on the basis of such judgements has substantial personal, societal, legal, political and ethical implications that should be balanced with the medical judgement during the pre-employment evaluation. The French Society of Occupational Medicine has therefore developed good practice guidelines for the management of LBP in workers exposed to manual handling of loads, including pre-employment examinations (Roquelaure and Petit 2013). We summarise here the main recommendations for the pre-employment examination of workers exposed to manual handling of loads.

\section{Methods}

The guidelines (Roquelaure and Petit 2013) were developed according to the Clinical Practice Guidelines method proposed by the French National Health Authority (HAS 2010). The guidelines are based on a systematic search of the literature undertaken from January 1990 to March 2012 in several databases (PubMed, Embase, NIOSHtic-2 and Cochrane Library), websites, institutional reports and documentation of the main international institutions in charge of occupational health. The guidelines were written by a multidisciplinary working group of 24 experts and reviewed by a multidisciplinary peer review committee of 50 experts (occupational health physicians, rheumatologists, National health insurance consultant physicians, rehabilitation physicians, general practitioners, physiotherapists, ergonomists, occupational therapists, occupational nurses, regional health inspectors, chiropractors, occupational risk epidemiologists and work physiology and ergonomics scientists). On the basis of the data published in the literature and professional opinions, the proposed guidelines are classified as grade $\mathrm{A}, \mathrm{B}$ or $\mathrm{C}$, according to the Oxford grading system (Oxford Centre for Evidence-Based Medicine):

Grade A-Established scientific evidence Based on studies with a high level of evidence, such as powerful randomized comparative trials with no major bias or metaanalysis of randomized comparative trials, decision analysis based on well-conducted studies.

Grade B-Scientific presumption Based on scientific presumption provided by studies with an intermediate level of evidence, such as less powerful randomized comparative trials, well-conducted non-randomized comparative studies, cohort studies. 
Grade C-Low level of evidence Based on studies with a lower level of evidence, such as case-control studies, retrospective studies, case series, comparative studies with considerable bias.

Grade EC-Expert consensus In the absence of studies, guidelines are based on a consensus between experts of the working party, after consulting the peer review group.

Detailed methodological information about search questions, the literature search, reviewing process and the consensus process is given in the guideline report (Roquelaure and Petit 2013).

\section{Results}

According to the literature, there is conflicting evidence regarding the effect of a pre-employment examination that included a physical capacity evaluation on LBP among workers that frequently perform lifting tasks. Due to the high rejection rate of candidates, a pre-employment medical examination is not recommended to reduce the risk of LBP (Kuijer et al. 2014; Mahmud et al. 2010). "In view of the high prevalence of 'simple' LBP (i.e. not causing functional disability in private life and/or at work) in the general population, it is not recommended to issue any medical contraindication to hiring for a job associated with a low back risk on the basis of a history of 'simple' nonspecific LBP (Grade EC)".

Guidelines regarding education and advice

In view of the high prevalence of nonspecific LBP in the workforce and the representations or 'beliefs' associated with these symptoms, the pre-employment examination also provides a good opportunity to deliver detailed information appropriate to each worker, especially concerning work-related risks, their prevention and possible medical follow-up.

Clinical examinations are a good opportunities to provide workers with valuable information concerning the diagnosis, management and prognosis of LBP. This discussion can have direct positive effects, as fears and beliefs may be identified and discussed. It can also help to restore confidence to workers who are sometimes confused by contradictory information or medical advice. Moreover, providing information concerning low back risk and LBP helps to improve a worker's understanding and promotes a positive change in workers' representations (fears and beliefs) and inappropriate behaviour (avoidance of movement) related to LBP (Grade B).

For workers with or without LBP exposed to manual handling of loads, it is recommended that:
- particular attention should be paid to the content of the message delivered by healthcare professionals in view of its potential impact on the worker's representations and behaviour (Grade B);

- the fact that LBP is common and frequently recurrent and that episodes of LBP are usually brief with a spontaneously favourable outcome should be emphasized (Grade B);

- the fact that the onset of LBP has a multifactorial origin and that occupational factors are one of the modifiable factors influencing the incidence of LBP should be emphasized (Grade B).

- the consistency of the risk prevention messages delivered by the multidisciplinary occupational health team should be ensured because of the negative impact of discordant messages (Grade EC).

Guidelines regarding clinical assessment

The recurrent nature of LBP means that previous history (frequency and duration of episodes) is the best predictor of future LBP (Dionne1999; Elders and Burdorf 2004). The literature identifies other factors that are also likely to be associated with future LBP and absenteeism: i.e. short free interval since the previous episode, sciatica associated with LBP, history of lumbar surgery, prolonged sick leave for LBP.

It is recommended that low back risk in workers with a history of 'severe' LBP should be evaluated (i.e. recurrent or chronic LBP and/or LBP causing functional disability in private life and/or at work). This evaluation should include at least:

1. The history of LBP (history, frequency, treatment and consequences), comorbidities and job history (Grade $E C$ ).

2. Assessment of the risks for the worker's health by taking into account the risks related to the job, potential job adjustments and socioeconomic context.

In complex medical cases (history of complex spinal surgery, severe comorbidities, etc.), it is recommended that a low back-focused physical examination should be performed and a consultation between the occupational physician and the general practitioner and/or specialist should be organized with the job applicant's consent (Grade EC).

Investigation of an asymptomatic spinal deformity (kyphosis, lordosis, scoliosis) has no particular value for surveillance or job fitness. In contrast, in the presence of serious and/or symptomatic spinal deformities, a specialist opinion should be obtained (Grade EC).

Due to the lack of predictive value of imaging on the development of future LBP or disability, it is not 
recommended that low back imaging be performed at the time of pre-employment health assessment (Grade A). These examinations expose job applicants to useless irradiation and can lead to rejection based on the state of health, which is ethically and legally unacceptable.

\section{Discussion}

These recommendations are the first occupational guidelines for the management of work-related LBP in France. They are adapted to the French system of occupational health, which includes occupational health services employing specialized occupational health physicians and nurses. However, they are also intended for the surveillance of workers in other European countries and for treating physicians (general practitioners, rheumatologists, rehabilitation physicians, orthopaedic surgeons, etc.) participating in the management of LBP. These recommendations are based on an extensive literature review and draw on recommendations of previous clinical practice guidelines related to the assessment and management of LBP at work (INSERM 2000; Mahmud et al. 2010; Waddell and Burton 2001). Few guidelines and systematic reviews have been published concerning pre-employment assessment for low back disorders in the workplace, and this is the reason why many recommendations have been based on low-grade evidence and expert consensus. However, the absence of grading does not mean that the guidelines are not relevant and useful, but indicates the need to conduct further studies. The main recommendations of these guidelines are: (1) medical contraindications alone should not exclude employment in a job associated with a low back risk on the basis of a history of 'simple' nonspecific LBP; (2) the relevance of examining a previous history of LBP, which is the best predictor of future LBP due to the recurrent nature of LBP. Psychosocial risk factors have voluntary not been developed in this part of the recommendations because they are better predictive markers of the risk of developing chronic pain and prolonged incapacity (Henschke et al. 2008; Linton 2005; Waddell and Aylward 2010).

Pre-employment examination is widely applied in most countries in the world because many employers and other stakeholders believe that health examinations of job applicants can prevent occupational diseases and sickness absences (Mohr et al. 1999; Pachman 2009). Controlling the incidence of work-related diseases is medically important, but it is of far greater importance for individual employees as they can result in life altering consequences for workers who depend on their physical well-being for their livelihood. Most workers who have experienced one episode of LBP do recover, returning to normal function at work and at home, but approximately
$10 \%$ of them will develop long-term pain and limitation of their ability to function at work and at home (Frank et al. 1998; Nachemson 1996; Waddell 1998). The loss of the ability to work can have devastating consequences on not only the injured individual but also his or her entire family. This small group accounts for the majority of LBP-related disability and the associated costs and absenteeism in working-age people (Turner et al. 2000; van Tulder et al. 1995).

There is a fine line between the risk of discrimination based on health and the regulatory requirement for prevention inherent to occupational health. The pre-employment examination must ensure that the worker's state of health is compatible with the requirements of the proposed job by taking the worker's medical and socioeconomic context into account. This could be counterbalanced by the argument that discrimination against candidates at high risk of above-average absence is justifiable because the employer has a right to expect employees to attend work regularly (Poole 1999). Although the physician's duty of care lies primarily towards the employer (to whom he also has a contractual obligation), he does ensure that the medical confidentiality is scrupulously observed. Ideally, a preemployment examination should not exclude impaired or at-risk workers but should strive to fit jobs to their abilities and provide counselling for risk management (Pachman 2009). Moreover, for unfit workers, the reasons for rejection of employment should be made clear, i.e. whether applicants are not fit to perform the tasks with work restrictions or because they are highly susceptible to risks (Sorgdrager et al. 2004).

\section{Conclusion}

Given that the prevalence of LBP in working-age adults is high and that manual handling of loads is a widespread activity among workers of many job categories, these guidelines correspond to a constant concern with prevention of occupational risk. Primarily intended for occupational physicians, these guidelines are also intended for general practitioners who carry out pre-employment examinations in many countries and are likely to be increasingly faced with this type of situation because of the combination of increasing work constraints with ageing of the workforce.

Acknowledgments The recommendations were elaborated in collaboration with the French Society for Occupational Health (SFMT), the French National Research and Safety Institute (INRS), the spine section of the French Society of Rheumatology (SFR), the French National Institute of Health and Medical Research (INSERM) and the Belgian Department of Occupational Health and Education for Health. The authors would like to thank the 23 members of the 
working party and Karine Petiprez, the project leader of the French National Health Authority, for her methodological support. The recommendations elaboration has received financial support from the General Directorate of Labour (DGT).

Conflict of interest The independence and impartiality of the working party and review committee's experts in relation to the topic of the guidelines were verified by an HAS entity devoted to management of conflicts of interest. There was no conflict of interest.

\section{References}

Bakker EW, Verhagen AP, van Trijffel E, Lucas C, Koes BW (2009) Spinal mechanical load as a risk factor for low back pain: a systematic review of prospective cohort studies. Spine (Phila $\mathrm{Pa}$ 1976) 34(8):E281-E293

Braddick MR, Atwell CP, Aw TC (1992) Audit of pre-employment health assessment in the National Health Service. Occup Med 42(1):36-38

Cox R, Edwards F, Palmer KT (2000) Fitness for work, the medical aspects, vol 3. Oxford Medical Publications, Oxford

da Costa BR, Vieira ER (2010) Risk factors for work-related musculoskeletal disorders: a systematic review of recent longitudinal studies. Am J Ind Med 53(3):285-323

Dionne CE (1999) Low back pain. In: Crombie IK, Croft PR, Linton SJ, LeResche L, Von Korff M (eds) Epidemiology of pain. IASP Press, Seattle, pp 283-287

Elders LA, Burdorf A (2004) Prevalence, incidence, and recurrence of low back pain in scaffolders during a 3-year follow-up study. Spine (Phila Pa 1976) 29(6):E101-E106

Elliott AM, Smith BH, Penny KI, Smith WC, Chambers WA (1999) The epidemiology of chronic pain in the community. Lancet 354(9186): 1248-1252

Frank J, Sinclair S, Hoggjohnson S, Shannon H, Bombardier C, Beaton D et al (1998) Preventing disability from work-related lowback pain-new evidence gives new hope-if we can just get all the players onside. Can Med Assoc J 158(12):1625-1631

HAS (2010) Elaboration de recommandations de bonne pratique. Recommandations pour la pratique clinique. Guide méthodologique (Elaboration of recommendations for good practice. Recommendations for clinical practice. Methodological guide). Haute autorité de santé (French National Health Authority). Saint-Denis la Plaine (in French)

Heneweer H, Staes F, Aufdemkampe G, van Rijn M, Vanhees L (2011) Physical activity and low back pain: a systematic review of recent literature. Eur Spine J 20(6):826-845

Henschke N, Maher CG, Refshauge KM, Herbert RD, Cumming RG, Bleasel J, York J, Das A, McAuley JH (2008) Prognosis in patients with recent onset low back pain in Australian primary care: inception cohort study. BMJ 7:337

Hoogendoorn WE, Poppel MNMv, Bongers PM, Koes BW, Bouter LM (1999) Physical load during work and leisure time as risk factors for back pain. Scand J Work Environ Health 25(5):387-403

Hulshof CT, Verbeek JH, van Dijk FJ, van der Weide WE, Braam IT (1999) Evaluation research in occupational health services: general principles and a systematic review of empirical studies. Occup Environ Med 56(6):361-377

INSERM (2000) Lombalgies en milieu professionnel. Quels facteurs de risque et quelle prévention? (low back pain at the workplace: risk factors and prevention). Les éditions INSERM, Paris

Johns RE Jr, Bloswick DS, Elegante JM, Colledge AL (1994) Chronic, recurrent low back pain. A methodology for analyzing fitness for duty and managing risk under the Americans with disabilities act. J Occup Med 36(5):537-547

Kuijer PP, Verbeek JH, Visser B, Elders LA, Van Roden N, Van den Wittenboer ME, Lebbink M, Burdorf A, Hulshof CT (2014) An evidence-based multidisciplinary practice guideline to reduce the workload due to lifting for preventing work-related low back pain. Ann Occup Environ Med 24(26):16

Kuiper J, Burdorf A, Verbeek JHAM, Frings-Dresen MHW, Beek AJvd, Viikari-Juntura ERA (1999) Epidemiologic evidence on manual materials handling as a risk factor for back disorders: a systematic review. Int J Ind Ergon 24:389-404

Linton SJ (2005) Do psychological factors increase the risk for back pain in the general population in both a cross-sectional and prospective analysis? Eur J Pain 9(4):355-361

Lotters F, Burdorf A, Kuiper J, Miedema H (2003) Model for the work-relatedness of low-back pain. Scand J Work Environ Health 29(6):431-440

Macfarlane GJ, Jones GT, Hannaford PC (2006) Managing low back pain presenting to primary care: Where do we go from here? Pain 122(3):219-222

Mahmud N, Schonstein E, Schaafsma F, Lehtola MM, Fassier JB, Reneman MF, Verbeek JH (2010) Pre-employment examinations for preventing occupational injury and disease in workers. Cochrane Database Syst Rev 8(12):CD008881

Manchikanti L (2000) Epidemiology of low back pain. Pain Physician 3(2):167-192

Mohr S, Gochfeld M, Pransky G (1999) Genetically and medically susceptible workers. Occup Med 14(3):595-611

Müller CF, Monrad T, Biering-Sørensen F, Darre E, Deis A, Kryger $P$ (1999) The influence of previous low back trouble, general health, and working conditions on future sick-listing because of low back trouble. A 15-year follow-up study of risk indicators for self-reported sick-listing caused by low back trouble. Spine 24(15):1562-1570

Nachemson AL (1996) Low back pain in the year 2000-"back" to the future. Bull Hosp Jt Dis 55(3):119-121

Nelson NA, Hughes RE (2009) Quantifying relationships between selected work-related risk factors and back pain. A systematic review of objective biomechanical measures and cost-related health outcomes. Int J Ind Ergon 39:202-210

Oxford Centre for Evidence-Based Medicine. Levels of evidence (2009). http://www.cebm.net/oxford-centre-evidence-based-medicine-levels-evidence-march-2009/

Pachman J (2009) Evidence base for pre-employment medical screening. Bull World Health Organ 87(7):529-534

Poole CJ (1999) Can sickness absence be predicted at the pre-placement health assessment? Occup Med (Lond) 49(5):337-339

Roquelaure Y, Petit A et les 22 membres du groupe de travail (2013) Surveillance médico-professionnelle du risque lombaire pour les travailleurs exposés à des manipulations de charges (Medical and occupational surveillance of the low back risk in workers exposed to manual handling of loads). Société Française de Médecine du Travail et Haute Autorité de Santé (French Society of Occupational Medicine). http://www.chu-rouen.fr/sfmt/autres/Argumentaire_scientifique.pdf (in French)

Serra C, Rodriguez MC, Delclos GL, Plana M, Gómez López LI, Benavides FG (2007) Criteria and methods used for the assessment of fitness for work: a systematic review. Occup Environ Med 64(5):304-312

Smedley J, Egger P, Cooper C, Coggon D (1997) Prospective cohort study of predictors of incident low back pain in nurses. BMJ 314(7089): 1225-1228

Sorgdrager B, Hulshof CT, van Dijk FJ (2004) Evaluation of the effectiveness of pre-employment screening. Int Arch Occup Environ Health 77(4):271-276 
Turner JA, Franklin G, Turk DC (2000) Predictors of chronic disability in injured workers: a systematic literature synthesis. Am J Ind Med 38(6):707-722

van Tulder MW, Koes BW, Bouter LM (1995) A cost-of-illness study of back pain in The Netherlands. Pain 62(2):233-240

Waddell G (1998) The back pain revolution. Churchill Livingstone, Edinburgh

Waddell G, Aylward M (2010) Models of sickness and disability. Applied to common health problems. The Royal Society of Medicine Press, London
Waddell G, Burton AK (2001) Occupational health guidelines for the management of low back pain at work: evidence review. Occup Med (Lond) 51(2):124-135

Whitaker S, Aw TC (1995) Audit of pre-employment assessments by occupational health departments in the National Health Service. Occup Med (Lond) 45(2):75-80 